\title{
ASSESSING THE EFFECT OF SUGAR TYPE AND FORM OF ITS INTAKE ON SELECTED PARAMETERS OF CARBOHYDRATE-LIPID METABOLISM AND PLASMA ATHEROGENIC INDICES IN RATS
}

\author{
Joanna Sadowska ${ }^{1}$, Magda Bruszkowska ${ }^{1}$ \\ ${ }^{1}$ West Pomeranian University of Technology in Szczecin, Faculty of Food Sciences and Fisheries, \\ Department of Human Nutrition Physiology, al. Piastów 17, 70-310 Szczecin, Poland
}

\begin{abstract}
Background. Over the past 50 years, the average consumption of sugar worldwide has tripled, also the type of consumed sugar has changed. Due to high price of sucrose and its technological disadvantages, high fructose corn syrup (HFCS) has become one of the most commonly used substitutes.

Objective. The aim of the study was to compare, on the animal model, the effect of sugar type (sucrose vs high fructose corn syrup $55 \%$ of fructose) and the sugar form (solid vs fluid and solid) on the chosen parameters of carbohydrate-lipid metabolism.

Material and methods. The experiment was carried out on 40 Wistar male rats aged 5 months, fed four isocaloric diets, containing: group I (SUC 15\%) fodder with 15\% sucrose, group II (HFCS 15\%) fodder with 15\% HFCS-55\%, group III (SUC 7.5\%+7.5\%) - 7.5\% sucrose in solid fodder and 7.5\% sucrose water solution, group IV (HFCS 7.5\%+7.5\%) - 7.5\% HFCS-55\% in solid fodder and 7.5\% HFCS water solution.

Results. The effect of HFCS-55 on the parameters of carbohydrate and lipid metabolism was not equivalent of the effect of sucrose. Dietary use of HFCS-55 instead of sucrose causes adverse changes in blood parameters of carbohydrate and lipid metabolism, particularly when provided in beverages, as at comparable weight gains to that of sucrose. More intense changes, manifesting in increased blood levels of glucose, triglycerides and uric acid, as well as increased liver fat content, were observed at simultaneous intake of sweeteners in solid foods and fluids, even with less sugar consumption, compared to solid food only.

Conclusions. Dietary use of HFCS-55 causes adverse changes in blood parameters of carbohydrate and lipid metabolism, as at comparable weight gains to that of sucrose. But liquid form of sugar intake is more important insulin resistance and cardiovascular disease risk factor than the sugar type.
\end{abstract}

Key words: carbohydrate-lipid metabolism, HFCS, sucrose, plasma atherogenic indices

\section{STRESZCZENIE}

Wprowadzenie. Konsumpcja cukrów przypadająca na statystycznego mieszkańca Ziemi na przestrzeni ostatnich pięćdziesięciu lat zwiększyła się trzykrotnie, zmienił się także rodzaj spożywanych cukrów. Ze względu na wysoką cenę sacharozy i jej wady technologiczne, wysokofruktozowy syrop kukurydziany (HFCS) stał się jednym z najczęściej używanych jej substytutów.

Cel badań. Celem pracy było porównanie, na modelu zwierzęcym, wpływu rodzaju cukru (sacharoza vs syrop fruktozowoglukozowy 55\%) oraz sposobu ich podania (pasza/płyn) na wielkość spożycia paszy, przyrosty masy ciała, odkładanie tkanki tłuszczowej oraz stężenia wybranych składników przemian węglowodanowo-lipidowych we krwi.

Material i metody. Doświadczenie przeprowadzono na 40 samcach szczura rasy Wistar w wieku 5 miesięcy, żywionych izokalorycznymi paszami: grupa I (SUC 15\%) - paszą z 15\% dodatkiem sacharozy, grupa II (HFCS 15\%) - paszą zawierającą 15\% syropu fruktozowo-glukozowego 55\%, grupa III - (SUC 7.5\%+7.5\%) - paszą zawierającą 7.5\% sacharozy i 7.5\% roztworu sacharozy podane w płynie, grupa IV (HFCS 7.5\%+7.5\%) - paszą zawierającą 7.5\% HFCS-55\% i 7.5\% roztworu HFCS podane w płynie.

Wyniki. Wpływ syropu fruktozowo-glukozowego 55\% na badane parametry gospodarki węglowodanowo-lipidowej nie był równoważny z wpływem sacharozy. Zastosowanie w diecie syropu fruktozowo-glukozowego 55\% zamiast sacharozy, powoduje niekorzystne zmiany parametrów węglowodanowo-lipidowych krwi, zwłaszcza jeśli podawany jest on w formie napoju, przy porównywalnym do sacharozy wpływie na przyrosty masy ciała. Bardziej intensywne zmiany, manifestujące się wyższym stężeniem glukozy, triglicerydów i kwasu moczowego we krwi, a także zwiększoną zawartością tłuszczu

Corresponding author: Magda Bruszkowska, Department of Human Nutrition Physiology, Faculty of Food Sciences and Fisheries, West Pomeranian University of Technology in Szczecin, Papieża Pawła street VI 3, 71-459 Szczecin, phone: +48 914496571 , e-mail: magda.bruszkowska@zut.edu.pl

(C) Copyright by the National Institute of Public Health - National Institute of Hygiene 
w wątrobie, obserwowano przy jednoczesnym przyjmowaniu cukrów w pokarmach stałych i płynach, nawet przy mniejszym spożyciu cukru, w porównaniu do podawania ich tylko z pokarmem stałym.

Wnioski. Zastosowanie w diecie HFCS-55 powoduje niekorzystne zmiany w parametrach węglowodanowo-lipidowych krwi, przy porównywalnych przyrostach masy ciała jak przy podaniu sacharozy. Jednak płynna forma podania cukrów jest większym czynnikiem ryzyka insulinooporności i chorób sercowo-naczyniowych niż rodzaj cukru.

Słowa kluczowe: metabolizm węglowodanowo-lipidowy, HFCS, sacharoza, wskaźniki aterogenności osocza

\section{INTRODUCTION}

Over the past 50 years, the average consumption of sugar worldwide has tripled, also the type of consumed sugar has changed $[25,44]$. Due to high price of sucrose and its technological disadvantages, high fructose corn syrup (HFCS) has become one of the most commonly used substitutes. Recently, the use of HFCS in food production in the Europe has increased by almost $100 \%$ [7].

Taking into account the time coincidence between the common introduction of HFCS in food production and observed increasing prevalence of obesity, the hypothesis was made that HFCS is one of the culprits for obesity [11, 38]. Moreover, such suggestions were made as some researchers equate the effect of HFCS with the one of pure fructose or high-fructose diet, of which negative effect on the lipid metabolism has been confirmed in numerous studies [21]. However, considering the composition of HFCS-42 (42\% fructose) and HFCS-55 (55\% fructose), the commonly used name 'high-fructose syrup' is misleading as they contain the amount of fructose similar to sucrose.

Yet still, causative links between the common use of HFCS and increasing prevalence of obesity are tested. So far, a correlation between the body weight and HFCS consumption in certain cases has not been assessed, because individual consumption of HFCS has not been monitored. Moreover, the experiments carried out did not result in unequivocal answers. Some of them show that the metabolic effects differ depending on the form of dietary intake, i.e. solid versus fluid [32]. Therefore, it was decided to test on an animal model how the intake of HFCS would affect the metabolism of carbohydrates and lipids and compare it to the effect of sucrose with regard to the form of sugar intake.

Studies on the effect of sucrose and HFCS on carbohydrate-lipid metabolism were carried out by Sadowska \& Bruszkowska [34], using a 10\% addition of the above mentioned sugars in solid form in the diet. They found a varied effect of the sugars used on the parameters tested. In our research, we decided to use the $15 \%$ amount of sugars and compare the intake of solid sugars in diet to sugars in solid and fluid form. The amount and form of sugars used reflects the average human intake. The greater amount of sugars can mask the differences in their impact caused by their different composition.

The aim of the study was to compare, on an animal model, the effect of sugar type (sucrose vs HFCS-55) and the form of its administration (solid vs fluid and solid) on the amount of consumed feed, body weight gain, fatty tissue depots, blood concentration of certain products of carbohydrate and lipid metabolism and plasma atherogenic indices.

\section{MATERIAL AND METHODS}

The experiment, after approval of the Ethics Commission (Approval no. 5/2013), was carried out on 40 Wistar male rats aged 5 months, of initial body weight $349 \pm 15.1 \mathrm{~g}$.

Following a week long conditioning, the animals were sorted into four groups $(n=10)$ of equal body weight $(349.6 \pm 14.7 \mathrm{~g})$, housed in individual cages, fed ad libitum on pelleted feeds.

Group I (SUC 15\%) received fodder 1 containing $15 \%$ sucrose, group II (HFCS $15 \%$ ) - fodder 2 containing $15 \%$ HFCS- $55 \%$, group III (SUC $7.5 \%+7.5 \%$ ) - fodder 3 with $7.5 \%$ sucrose, group IV (HFCS 7.5\%+7.5\%) - fodder 4 containing $7.5 \%$ HFCS-55\%. Selection of HFCS-55\% resulted from the fact that it contains more fructose (than HFCS-42), which exerts adverse metabolic effects (than glucose) and is more popular in food technology. Fodders were designed to reflect the changes taking place today in the composition of diets, which contains simple sugars and refined carbohydrates. Detailed composition of fodders used in the experiment are presented in Table 1. The prepared fodders were subjected to chemical analysis [3] to determine the contents of total nitrogen (by Kjeldahl's method, on Kjeltec 2100 apparatus), converted to quantity of protein, crude fat (by Soxhlet's method, on Soxtec 1046 apparatus), dry matter, ash (by a gravimetric method) and fiber (in an ANKOM 220 apparatus). The content of digested carbohydrates was calculated from the difference between dry matter and the remaining solid components - Table 1. The metabolic energy was calculated using commonly applied energy equivalents: protein $-4.0 \mathrm{kcal} / \mathrm{g}(16.76 \mathrm{~kJ} / \mathrm{g})$, fat $-9.0 \mathrm{kcal} / \mathrm{g}(37.71$ $\mathrm{kJ} / \mathrm{g})$, digested carbohydrates $-4.0 \mathrm{kcal} / \mathrm{g}(16.76 \mathrm{~kJ} / \mathrm{g})$. 
Table 1. Component and chemical composition of fodders used in the experiment

\begin{tabular}{|c|c|c|c|c|}
\hline Component & Fodder 1 & Fodder 2 & Fodder 3 & Fodder 4 \\
\hline Wheat $(\mathrm{g} / 100 \mathrm{~g})$ & 6 & 6 & 6 & 6 \\
\hline Corn grain $(\mathrm{g} / 100 \mathrm{~g})$ & 10 & 10 & 10 & 10 \\
\hline Wheat bran (g/100 g) & 20 & 20 & 20 & 20 \\
\hline Dry whey $(\mathrm{g} / 100 \mathrm{~g})$ & 3 & 3 & 3 & 3 \\
\hline Fodder salt ${ }^{1}(\mathrm{~g} / 100 \mathrm{~g})$ & 0.3 & 0.3 & 0.3 & 0.3 \\
\hline Soya-bean grain $(\mathrm{g} / 100 \mathrm{~g})$ & 17 & 17 & 17 & 17 \\
\hline Fodder chalk ${ }^{2}(\mathrm{~g} / 100 \mathrm{~g})$ & 1.5 & 1.5 & 1.5 & 1.5 \\
\hline Phosphate 2-CA $\mathrm{CA}^{3}(\mathrm{~g} / 100 \mathrm{~g})$ & 0.8 & 0.8 & 0.8 & 0.8 \\
\hline Premix LRM ${ }^{4}(\mathrm{~g} / 100 \mathrm{~g})$ & 1 & 1 & 1 & 1 \\
\hline Wheat flour (g/100 g) & 25.4 & 25.4 & 32.9 & 32.9 \\
\hline Sucrose $(g / 100 \mathrm{~g})$ & 15 & - & 7.5 & - \\
\hline High fructose corn syrup-55 (in powder) (g/100 g) & - & 15 & - & 7.5 \\
\hline $\begin{array}{l}\text { Total protein }(\%) \\
\% \text { of diet energy }\end{array}$ & $\begin{array}{l}15.3 \pm 0.54 \\
18.6\end{array}$ & $\begin{array}{l}15.3 \pm 0.62 \\
18.4\end{array}$ & $\begin{array}{l}16.1 \pm 0.71 \\
19.6\end{array}$ & $\begin{array}{l}16.2 \pm 0.48 \\
19.7\end{array}$ \\
\hline $\begin{array}{l}\text { Crude fat }(\%) \\
\% \text { of diet energy }\end{array}$ & $\begin{array}{l}2.91 \pm 0.11 \\
8.0\end{array}$ & $\begin{array}{l}2.99 \pm 0.09 \\
8.10\end{array}$ & $\begin{array}{l}3.15 \pm 0.22 \\
8.64\end{array}$ & $\begin{array}{l}3.16 \pm 0.12 \\
8.64\end{array}$ \\
\hline $\begin{array}{l}\text { Carbohydrates }(\%) \\
\text { total } \\
\text { fiber } \\
\text { digested } \\
\% \text { of diet energy }\end{array}$ & $\begin{array}{c}65.5 \pm 0.54 \\
5.36 \pm 0.13 \\
60.1 \pm 0.51 \\
73.3\end{array}$ & $\begin{array}{l}66.2 \pm 0.48 \\
5.21 \pm 0.15 \\
61.0 \pm 0.45 \\
\quad 73.5\end{array}$ & $\begin{array}{l}63.8 \pm 0.51 \\
5.07 \pm 0.09 \\
58.7 \pm 0.54 \\
\quad 71.6\end{array}$ & $\begin{array}{l}64.0 \pm 0.62 \\
5.08 \pm 0.10 \\
59.0 \pm 0.65 \\
71.7\end{array}$ \\
\hline Dry matter $(\%)$ & $89.1 \pm 0.20$ & $89.9 \pm 0.12$ & $88.7 \pm 0.17$ & $89.0 \pm 0.11$ \\
\hline Total ash $(\%)$ & $5.38 \pm 0.14$ & $5.38 \pm 0.10$ & $5.67 \pm 0.08$ & $5.59 \pm 0.09$ \\
\hline $\begin{array}{l}\text { Metabolizable energy } \\
(\mathrm{kcal} / \mathrm{g})(\mathrm{kJ} / \mathrm{g})\end{array}$ & $\begin{array}{l}3.28 \pm 0.03 \\
13.7 \pm 0.20\end{array}$ & $\begin{array}{l}3.32 \pm 0.04 \\
13.9 \pm 0.19\end{array}$ & $\begin{array}{l}3.28 \pm 0.07 \\
13.7 \pm 0.22\end{array}$ & $\begin{array}{l}3.29 \pm 0.02 \\
13.8 \pm 0.17\end{array}$ \\
\hline Part of energy from added sugars in fodder $(\%)$ & 18.3 & 18.1 & 9.1 & 9.1 \\
\hline $\begin{array}{l}\text { Part of energy from added sugars in diet* }(\%) \\
\text { including fructose }(\%)\end{array}$ & $\begin{array}{l}18.3 \\
9.15\end{array}$ & $\begin{array}{l}18.1 \\
9.95\end{array}$ & $\begin{array}{l}18.3 \\
9.15\end{array}$ & $\begin{array}{l}18.2 \\
10.0\end{array}$ \\
\hline
\end{tabular}

For drinking animals from I and II group received settled tap water, animals in group III received $25 \mathrm{ml}$ of $7.5 \%$ sucrose water solution, and the animals of group IV - $25 \mathrm{ml}$ of $7.5 \%$ HFCS- $55 \%$ water solution. After drinking sugars solutions animals received settled tap water. The application rate of solutions and the concentration of sugars in them calculated so that the consumption of added sugars in all groups of animals was similar and amounted to approx. $18 \%$ of the energy value of the diet. This amount was used, taking into account the composition of the modern diet of many people in the diet which the share of added sugars is up to $20 \%$, provided both in the solid foods and beverages [41].

\section{Analyses}

The experiment lasted for six weeks, the amount of diets consumed by the animals were recorded daily, once a week the animals were weighted (Radwag PM 10.C32 Precision Scales). On the completion of the experiment, the animals were fasted overnight $(12 \mathrm{~h})$, and anaesthetised with an intramuscular injection (10 mg/kg b.m.) of Ketanest (Pfizer Ireland Pharmaceuticals). During fasting, the animals of all groups only had access to water. Blood was sampled from heart to tubes with anticoagulant and centrifuged, at $2000 \mathrm{~g}$ for $10 \mathrm{~min}$. at $4^{\circ} \mathrm{C}$. Plasma samples were stored at $4^{\circ} \mathrm{C}$ and assayed within $24 \mathrm{~h}$.

Peri-cardial, intraperitoneal and retroperitoneal fat was dissected and weighted. Thigh muscles (triceps femoris) and livers were dissected and used to determine the percentage of crude fat, with the Soxhlet technique in Soxtec HT6 apparatus (Foss Tecator).

Blood plasma was assayed for the concentration of glucose (BioSystems ref. no 11503), triglycerides (BioSystems ref. no 11528), HDL-chol. (BioSystems ref. no 11557), LDL-chol. (BioSystems ref. no 11579), total cholesterol (BioSystems ref. no 11505), uric acid (BioSystems ref. no 11521) with colorimetric method on the Metertech spectrophotometer. Insulin (ref. no DE2048, Rat ELISA kit Demeditec Diagnostics, Kiel, Germany) was assayed using a monoclonal antibody against rat insulin. To quantify insulin resistance and beta-cell function homeostatic model assessment 
(HOMA) was used, where: HOMA-IR = fasting glucose $[\mathrm{mmol} / \mathrm{L}] \mathrm{x}$ fasting insulin $[\mathrm{mU} / \mathrm{L}] / 22.5$.

The plasma atherogenic ratios were calculated as follows [4]:

Atherogenic Index of Plasma (AIP) $=\log \{\mathrm{TG}[\mathrm{mmol} / \mathrm{L}] /$ HDL-C $[\mathrm{mmol} / \mathrm{L}]\}$

Castelli's Risk Index I (CRI-I) $=$ TC $[\mathrm{mmol} / \mathrm{L}] / \mathrm{HDL}-\mathrm{C}$ [mmol/L]

Castelli's Risk Index II (CRI-II) = LDL-C $[\mathrm{mmol} / \mathrm{L}] /$ $\mathrm{HDL}-\mathrm{C}[\mathrm{mmol} / \mathrm{L}]$

Atherogenic Coefficient $(\mathrm{AC})=\{\mathrm{TC}[\mathrm{mmol} / \mathrm{L}]-\mathrm{HDL}-\mathrm{C}$ $[\mathrm{mmol} / \mathrm{L}]\} / \mathrm{HDL}-\mathrm{C}[\mathrm{mmol} / \mathrm{L}]$.

\section{Statistics}

The resulting data, after checking normality of distribution (Shapiro-Wilk test) and homogeneity of variance (Leven's test), were analyzed by two-way
ANOVA statistics for factorial designs, with regard to sugar type (ST) and sugar form (SF) of intake. If the interaction occurred, the post hoc Tukey's test was used. Analyzes were carried out in the Statistica $12.0 \AA$ computer program.

\section{RESULTS}

Analysis of the obtained results has revealed, that the type of sugar had no statistically significant effect on the feed and energy intake (Table 2). The feed intake ( $\mathrm{g} / 100 \mathrm{~g}$ body weight/day) was affected by the sugar form and the interaction occurred between sugar type and sugar form. Administration of sugars in the liquid decreased feed intake, but statistically significant differences were observed only in animals fed on sucrose compared to the other groups.

Table 2. Effect of diet type on feed and energy intake in rats, $\bar{x} \pm \mathrm{SD}, \mathrm{n}=40$

\begin{tabular}{|c|c|c|c|c|c|c|c|}
\hline Trait & $\begin{array}{l}\text { SUC } \\
15 \% \\
\end{array}$ & $\begin{array}{c}\text { HFCS } \\
15 \% \\
\end{array}$ & $\begin{array}{c}\text { SUC } \\
7.5+7.5 \%\end{array}$ & $\begin{array}{c}\text { HFCS } \\
7.5+7.5 \%\end{array}$ & ST & SF & $\begin{array}{c}\text { I } \\
\text { STxSF }\end{array}$ \\
\hline Feed intake (g/day) & $29.3 \pm 1.82$ & $28.7 \pm 1.61$ & $26.3 \pm 1.84$ & $27.2 \pm 1.55$ & $\mathrm{p} \leq 0.239$ & $\mathrm{p} \leq 0.000 * *$ & $\mathrm{p} \leq 0.171$ \\
\hline Feed intake (g/100 g body weight/day) & $6.31 \pm 0.21^{\mathrm{b}}$ & $6.14 \pm 0.25^{\mathrm{b}}$ & $5.57 \pm 0.18^{\mathrm{a}}$ & $5.83 \pm 0.38^{\mathrm{b}}$ & $\mathrm{p} \leq 0.591$ & $\mathrm{p} \leq 0.000 * *$ & $\mathrm{p} \leq 0.018^{*}$ \\
\hline Energy value of feed consumed (kcal/day) & $97.5 \pm 6.14$ & $98.3 \pm 5.52$ & $87.2 \pm 6.21$ & $92.1 \pm 5.29$ & $\mathrm{p} \leq 0.120$ & $\mathrm{p} \leq 0.000 * *$ & $\mathrm{p} \leq 0.259$ \\
\hline Energy value of liquid consumed (kcal/day) & 0 & 0 & $6.55 \pm 0.60$ & $6.16 \pm 0.94$ & $\mathrm{p} \leq 0.272$ & & \\
\hline Energy value of diet (kcal/day) & $97.5 \pm 6.14$ & $98.3 \pm 5.52$ & $93.7 \pm 5.92$ & $98.3 \pm 5.39$ & $\mathrm{p} \leq 0.143$ & $\mathrm{p} \leq 0.302$ & $\mathrm{p} \leq 0.300$ \\
\hline Energy value of diet (kcal/100 g b.w./day) & $21.4 \pm 0.72$ & $21.1 \pm 0.86$ & $20.3 \pm 0.53$ & $21.1 \pm 1.27$ & $\mathrm{p} \leq 0.088$ & $\mathrm{p} \leq 0.364$ & $\mathrm{p} \leq 0.053$ \\
\hline Added sugar intake in fodder (g/day) & $4.39 \pm 0.32^{b}$ & $4.3 \pm 0.12^{b}$ & $1.97 \pm 0.22^{\mathrm{a}}$ & $2.04 \pm 0.10^{\mathrm{a}}$ & $\mathrm{p} \leq 0.359$ & $\mathrm{p} \leq 0.000 * *$ & $\mathrm{p} \leq 0.355$ \\
\hline Added sugar intake in fluid (g/day) & 0 & 0 & $1.64 \pm 0.18$ & $1.54 \pm 0.15$ & $\mathrm{p} \leq 0.469$ & & \\
\hline Total added sugar intake (g/day) & $4.39 \pm 0.32$ & $4.3 \pm 0.12$ & $3.61 \pm 0.28$ & $3.58 \pm 0.40$ & $\mathrm{p} \leq 0.259$ & $\mathrm{p} \leq 0.039 *$ & $\mathrm{p} \leq 0.371$ \\
\hline Total added sugar intake (g/100 g b.w. /day) & $0.96 \pm 0.058$ & $0.92 \pm 0.074$ & $0.78 \pm 0.051$ & $0.77 \pm 0.061$ & $\mathrm{p} \leq 0.339$ & $\mathrm{p} \leq 0.034 *$ & $\mathrm{p} \leq 0.472$ \\
\hline
\end{tabular}

It was found that sugar type and the form of its intake had no statistically significant effect on the weight gains in tested animals, nor on the amount of periorgan fatty tissue and muscle fat (Table 3). But significant influence of the sugar form and the interaction between the sugar type and form of its administration on the hepatic fat content were found. The hepatic fat content was higher in animals received sugars in feed and fluid compared to those receiving them only in feed. The liver fat was the highest in the SUC 7.5\% $+7.5 \%$ group and the lowest in the SUC $15 \%$ group.

Table 3. Effect of diet type on body weight gain and fat deposition in male rats, $\bar{x} \pm \mathrm{SD}, \mathrm{n}=40$

\begin{tabular}{|c|c|c|c|c|c|c|c|}
\hline Trait & $\begin{array}{l}\text { SUC } \\
15 \%\end{array}$ & $\begin{array}{c}\text { HFCS } \\
15 \%\end{array}$ & $\begin{array}{c}\text { SUC } \\
7.5+7.5 \%\end{array}$ & $\begin{array}{c}\text { HFCS } \\
7.5+7.5 \%\end{array}$ & ST & SF & $\begin{array}{c}\text { I } \\
\text { STxSF }\end{array}$ \\
\hline Initial body weight (g) & $349.3 \pm 15.0$ & $349.6 \pm 13.7$ & $351.1 \pm 14.6$ & $348.7 \pm 15.7$ & $\mathrm{p} \leq 0.920$ & $\mathrm{p} \leq 0.822$ & $\mathrm{p} \leq 0.772$ \\
\hline Final body weight $(\mathrm{g})$ & $456.3 \pm 28.9$ & $466.6 \pm 25.9$ & $461.1 \pm 26.8$ & $464.7 \pm 14.8$ & $\mathrm{p} \leq 0.335$ & $\mathrm{p} \leq 0.835$ & $\mathrm{p} \leq 0.688$ \\
\hline Body weight gain (g/6 weeks) & $107 \pm 21.1$ & $117 \pm 26.5$ & $110 \pm 14.7$ & $116 \pm 13.8$ & $\mathrm{p} \leq 0.175$ & $\mathrm{p} \leq 0.855$ & $\mathrm{p} \leq 0.781$ \\
\hline Body weight gain $(\mathrm{g} / 100 \mathrm{kcal})$ & $2.60 \pm 0.341$ & $2.83 \pm 0.544$ & $2.79 \pm 0.245$ & $2.83 \pm 0.353$ & $\mathrm{p} \leq 0.259$ & $\mathrm{p} \leq 0.435$ & $\mathrm{p} \leq 0.449$ \\
\hline Peri-cardial fat $(\mathrm{g})$ & $0.678 \pm 0.157$ & $0.647 \pm 0.093$ & $0.732 \pm 0.154$ & $0.710 \pm 0.111$ & $\mathrm{p} \leq 0.517$ & $\mathrm{p} \leq 0.157$ & $\mathrm{p} \leq 0.914$ \\
\hline Peri-cardial fat ( $\mathrm{g} / 100 \mathrm{~g}$ body weight) & $0.147 \pm 0.03$ & $0.140 \pm 0.02$ & $0.160 \pm 0.04$ & $0.153 \pm 0.02$ & $\mathrm{p} \leq 0.344$ & $\mathrm{p} \leq 0.132$ & $\mathrm{p} \leq 0.918$ \\
\hline Peri-cardial fat $(\mathrm{mg} / 100 \mathrm{kcal})$ & $16.4 \pm 3.14$ & $15.7 \pm 1.99$ & $18.7 \pm 4.50$ & $17.2 \pm 2.21$ & $\mathrm{p} \leq 0.231$ & $\mathrm{p} \leq 0.059$ & $\mathrm{p} \leq 0.687$ \\
\hline Peri-intestinal fat $(\mathrm{g})$ & $1.618 \pm 0.268$ & $1.740 \pm 0.188$ & $1.628 \pm 0.291$ & $1.823 \pm 0.270$ & $\mathrm{p} \leq 0.054$ & $\mathrm{p} \leq 0.565$ & $\mathrm{p} \leq 0.653$ \\
\hline Peri-intestinal fat ( $\mathrm{g} / 100 \mathrm{~g}$ body weight) & $0.354 \pm 0.054$ & $0.372 \pm 0.030$ & $0.352 \pm 0.056$ & $0.392 \pm 0.058$ & $\mathrm{p} \leq 0.072$ & $\mathrm{p} \leq 0.582$ & $\mathrm{p} \leq 0.493$ \\
\hline Peri-intestinal fat (mg/100 kcal) & $39.4 \pm 5.78$ & $42.2 \pm 4.19$ & $41.1 \pm 5.62$ & $44.2 \pm 6.61$ & $\mathrm{p} \leq 0.106$ & $\mathrm{p} \leq 0.298$ & $\mathrm{p} \leq 0.921$ \\
\hline Muscle fat $(\%)$ & $3.16 \pm 0.321$ & $3.37 \pm 0.516$ & $3.16 \pm 0.250$ & $3.36 \pm 0.441$ & $\mathrm{p} \leq 0.117$ & $\mathrm{p} \leq 0.996$ & $\mathrm{p} \leq 0.942$ \\
\hline Liver fat (\%) & $2.86 \pm 0.111^{\mathrm{a}}$ & $2.99 \pm 0.095^{\mathrm{b}}$ & $3.20 \pm 0.120^{\mathrm{c}}$ & $3.09 \pm 0.105^{\mathrm{bc}}$ & $\mathrm{p} \leq 0.693$ & $\mathrm{p} \leq 0.000 * *$ & $\mathrm{p} \leq 0.001 * *$ \\
\hline
\end{tabular}

$\mathrm{a}, \mathrm{b}, \mathrm{c}-$ means denoted different letters in the same line are statistically different, $\mathrm{p} \leq 0.05$.

$* *$ - statistical difference, $\mathrm{p} \leq 0.01$

$\mathrm{ST}$ - sugar type, SF - sugar form, I STxSF - interaction sugar type x sugar form, SUC - sucrose groups, HFCS - high fructose corn syrup groups 
The sugar type and form affected statistically significantly plasm concentration of glucose and triglycerides - table 4 . They were higher in animals on HFCS-55 diet comparing to those on sucrose diet, and in animals receiving sugars in fodders and fluids comparing to those on solid sugars only (Table 4). The form of sugar intake had a statistically significant effect on the insulin concentration and the HOMA-IR index value. They were higher in animals provided with solid and fluid sugars, even with less sugar consumption, compared to those fed on solid sugars only.

Table 4. Effect of diet type on glucose, lipids, the value of atherogenic indices and uric acid level in plasma of male rats, $\bar{x} \pm \mathrm{SD}$, $\mathrm{n}=40$

\begin{tabular}{|l|c|c|c|c|c|c|c|}
\hline \multicolumn{1}{|c|}{ Trait } & SUC & HFCS & SUC & HFCS & ST & SF & I \\
\hline Glucose (mmol/L) & $7.88 \pm 0.74$ & $8.52 \pm 0.96$ & $8.60 \pm 0.57$ & $8.93 \pm 0.86$ & $* \mathrm{p} \leq 0.041$ & $* \mathrm{p} \leq 0.039$ & $\mathrm{p} \leq 0.472$ \\
\hline Insulin (mU/L) & $6.54 \pm 1.41$ & $5.82 \pm 1.15$ & $7.97 \pm 1.0$ & $8.23 \pm 1.63$ & $\mathrm{p} \leq 0.523$ & $* \mathrm{p} \leq 0.012$ & $\mathrm{p} \leq 0.312$ \\
\hline HOMA-IR & $2.29 \pm 0.51$ & $2.20 \pm 0.47$ & $3.05 \pm 0.61$ & $3.27 \pm 0.39$ & $\mathrm{p} \leq 0.689$ & $* \mathrm{p} \leq 0.026$ & $\mathrm{p} \leq 0.283$ \\
\hline Triglycerides (mmol/L) & $0.333 \pm 0.052$ & $0.426 \pm 0.092$ & $0.446 \pm 0.075$ & $0.522 \pm 0.088$ & $* * \mathrm{p} \leq 0.001$ & $* * \mathrm{p} \leq 0.000$ & $\mathrm{p} \leq 0.743$ \\
\hline Total cholesterol (mmol/L) & $2.12 \pm 0.31$ & $2.0 \pm 0.16$ & $2.05 \pm 0.30$ & $2.14 \pm 0.23$ & $\mathrm{p} \leq 0.889$ & $\mathrm{p} \leq 0.648$ & $\mathrm{p} \leq 0.223$ \\
\hline HDL-chol. (mmol/L) & $0.85 \pm 0.20$ & $0.87 \pm 0.14$ & $0.79 \pm 0.08$ & $0.79 \pm 0.13$ & $\mathrm{p} \leq 0.888$ & $\mathrm{p} \leq 0.112$ & $\mathrm{p} \leq 0.764$ \\
\hline LDL-chol. (mmol/L) & $0.91 \pm 0.09$ & $0.88 \pm 0.11$ & $0.85 \pm 0.09$ & $0.94 \pm 0.11$ & $\mathrm{p} \leq 0.302$ & $\mathrm{p} \leq 0.982$ & $\mathrm{p} \leq 0.084$ \\
\hline AIP & $-0.420 \pm 0.044$ & $-0.333 \pm 0.049$ & $-0.254 \pm 0.084$ & $-0.179 \pm 0.120$ & $* * \mathrm{p} \leq 0.001$ & $* * \mathrm{p} \leq 0.000$ & $\mathrm{p} \leq 0.822$ \\
\hline CR-I & $2.44 \pm 0.33$ & $2.33 \pm 0.25$ & $2.59 \pm 0.36$ & $2.78 \pm 0.53$ & $\mathrm{p} \leq 0.664$ & $* \mathrm{p} \leq 0.017$ & $\mathrm{p} \leq 0.226$ \\
\hline CR-II & $1.05 \pm 0.14$ & $1.02 \pm 0.10$ & $1.08 \pm 0.13$ & $1.23 \pm 0.53$ & $\mathrm{p} \leq 0.231$ & $* \mathrm{p} \leq 0.045$ & $\mathrm{p} \leq 0.129$ \\
\hline AC & $1.44 \pm 0.33$ & $1.33 \pm 0.25$ & $1.59 \pm 0.36$ & $1.78 \pm 0.53$ & $\mathrm{p} \leq 0.664$ & $* \mathrm{p} \leq 0.017$ & $\mathrm{p} \leq 0.226$ \\
\hline Uric acid (mg/dl) & $0.997 \pm 0.339$ & $0.937 \pm 0.311$ & $1.256 \pm 0.343$ & $1.370 \pm 0.405$ & $\mathrm{p} \leq 0.948$ & $* * \mathrm{p} \leq 0.002$ & $\mathrm{p} \leq 0.537$ \\
\hline
\end{tabular}

$*, * *$ - statistical difference, $* \mathrm{p} \leq 0.05, * * \mathrm{p} \leq 0.01$

$\mathrm{ST}$ - sugar type, SF - sugar form, I STxSF - interaction sugar type x sugar form, SUC - sucrose groups, HFCS - high fructose corn syrup groups. AIP Atherogenic Index of Plasma, CRI-I - Castelli's Risk Index I, CRI-II - Castelli's Risk Index II, AC - Atherogenic Coefficient.

Neither sugar type nor the form of its intake had any statistically significant effect on the concentrations of total cholesterol and its fractions (HDL and LDL). The form of sugar intake had a significant effect on the concentration of uric acid. Its higher concentration was observed in animals on sugars derived from solid foods and fluids comparing to those on sugars derived from solid foods only.

The form of sugar had a statistically significant effect on all the atherogenic indices. They were more atherogenic in animals provided with solid and fluid sugars compared to those fed on solid sugars only. Only AIP was decreased both by dietary HFCS and if added sugars were provided in a liquid and solid form (Table 4).

\section{DISCUSSION}

A lower intake of feed was observed in animals provided with sugar-sweetened fluid, but in this respect only the effect of sucrose was statistically significant.
Similar results were obtained by Tsanzi et al. [40] and Light et al. [23] in female rats provided with HFCS-55 or sucrose-sweetened water.

Lower feed intake by animals provided with sugar solution resulted in the comparable energy intake in all the treatment groups. Such compensational decrease in energy intake from solid foods resulting from energy added in drinks was reported by Roy et al. [33] for rats, and by Gadah et al. [15] for humans. Studies conducted by Chen et al. [8] and O'Connor et al. [31], however, demonstrated that energy provided with drinks is considered additional one, it is not compensated by lower feed intake, which results in increased energy value of diet. Therefore, meeting the energy requirements in animals seems to be predominant in the regulation of food intake. Emotional factors, increasing significantly food intake in humans, are non-existent in the studies based on animal models. The lack of differences in the energy intake observed in this study could have resulted from the fact that the sweetened fluids were not provided 
ad libitum but only in the amount providing $7.5 \%$ of dietary sugar, which was adequate to the sugar intake by rats only on solid foods.

Weight gains of the tested animals were not affected by the sugar type and form. Opposite results were obtained by Bocarsly et al. [5] who reported higher weight gains in animals receiving HFCS compared to animals on sucrose drinks. However Bocarsly et al. [5] provided only fluid sugars. The form of sugar intake may modify the rate of absorbing monosaccharides, elevate the glycemic effect and stimulate insulin release. Additionally, sweetened drinks may cause lower thermogenesis which contributes to a positive energy balance [14]. The lack of differences in the weight gains in our experiment could have resulted from the high total sugar intake, regardless of sugar type. Sugars accounted for as much as $15 \%$ of diet, and weight gains were considerable in all the animals (ca. $110 \mathrm{~g} / 6$ weeks). In a similar study, but with different amount of sucrose (10\%), Goluch-Koniuszy \& Sadowska [17] observed weight gains in males at $42 \mathrm{~g} / 6$ weeks.

No differences between treatment groups were found in the amount of pericardial and per-intestinal fat. Also studies carried out by Light et al. [23] on female rats did not result in statistically significant differences in fatty depots around gonads or in the retroperitoneal space between the groups treated with $13 \%$ HFCS-55 or $13 \%$ sucrose. Sugar type had no statistically significant effect on the liver and muscle fat. Also Bravo et al. [6] stated that consumption of sucrose or HFCS does not increase liver fat or ectopic fat depots in muscles. But in this study the liquid sugar form increased liver fat content.

The sugar type and form of its intake affected statistically significantly the concentrations of glucose and triglycerides. They were higher in animals on the HFCS diet and in animals fed on sugars in solid foods and fluids. The crucial role in regulating fasting blood glucose concentration is played by the glucostatic function of liver in which the gluconeogenesis takes place. The process goes faster at lower insulin levels or with insulin resistance. Studies conducted by Dirlewanger et al. [10] demonstrated that fructose induces the hepatic insulin resistance and impaired inhibition of gluconeogenesis by insulin in liver. It has been also reported that fructose may reduce the synthesis of adiponectin which stimulates binding glucose to cells and inhibits gluconeogenesis [36].

The sugar type had no effect on insulin concentration and HOMA-IR index value. Similar results were also reported by Monsivais et al. [28] in rats, Akhavan \& Anderson [2] in men, and Melanson et al. [27] in women and Soenen \& Westerterp-Plantenga [37] in men and women.
The elevated concentration of blood glucose in male rats fed on the HFCS-55 could be also result of elevated concentration of triglycerides that decrease tissue sensitivity to insulin and stimulate glucose synthesis in liver. But on the other hand elevation of triglycerides may also be a consequence of insulin resistance. Considering higher insulin level and HOMA-IR index values in animals receiving sugars in feed and liquid, it can be assumed that higher triglycerides concentrations in these animals may be a consequence of insulin resistance.

Similar results were obtained by Akar et al. [1] and Bocarsly et al. [5]. They reported elevated triglyceride levels in the blood of male rats fed on HFCS-55 compared to those fed on sucrose. But no influence on the short term endocrine and metabolic effects of consuming HFCS-sweetened beverages stated Heden et al. [18].

The concentration of triglycerides reflects the amount of plasma VLDL. A number of studies demonstrate that fructose increased VLDL secretion [35]. Fructose also reduces the plasma elimination of VLDL [9]. Impaired hydrolysis of triglycerides from VLDL hinders their storage in fatty tissue and elevates their blood level. It explains why animals fed the HFCS-55 diet have changed lipid parameters in blood without significantly increased fatty tissue depots.

The difference between the amount of fructose derived from sucrose or HFCS in this study was not big and accounted for $9.3 \%(9.15 \%$ vs. $10.0 \%)$. However, the obtained results allow to state that due to multiplicity of mechanisms through which fructose may affect parameters of carbohydrate and lipid metabolism, adverse changes in these parameters may occur even at slight changes in dietary fructose content.

The elevated blood levels of triglycerides and glucose observed in animals receiving sugars in solid and fluid form, with slightly increased depots of periorgan fat may indicate that the animals were developing insulin resistance, which was confirmed by higher insulin concentration and a higher HOMAIR index. $M a$ et al. [26] showed that regular sweet beverages intake is associated with an insulin resistance and a higher risk of developing prediabetes.

In this study no effect of the examined factors was observed on blood cholesterol levels and its fractions. Also Akar et al. [1], Light et al. [23] and Lowndes et al. [24] did not observe any HFCS effect of the levels of total cholesterol and HDL-cholesterol in male rats. The opposite results were obtained by Figlewicz et al. [13] and Ferder et al. [12].

In order to assess the CVD risk in this study, the following atherogenic markers were applied: CR-I, CR-II, AIP, and AC, which prove to be very useful 
in estimating the CVD risk when LDL-C levels are similar $[29,19,39]$. All of the indices were work out for humans. There are no reference values for them in rats, but they can be useful in animals groups comparisons in terms of the risk of cardiovascular diseases. Values of these indicators were less favorable in rats receiving sugars in liquid and solid form. Sugar type has no effect. Sadowska \& Bruszkowska [34] were found that using HFCS-55 instead of sucrose has an adverse effect on blood lipid parameters and plasma atherogenic indices. However, in their studies only solid sugars were used, and their amount was lower $(10 \%)$.

The level of uric acid is often used as a marker for cardiovascular diseases. The acid is a key factor in the pathomechanism of forming and developing atherosclerotic plaque, and by causing endothelium dysfunctions it contributes to hypertension [20]. The study also demonstrated uric acid relation to the development of insulin resistance [43].

Similarly to this study, in the studies carried out by $Y u$ et al. [42] and $L e$ et al. [22] no difference in the effect of sucrose and HFCS was found on uric acid blood level. But in our study, the concentration of uric acid was influenced by the sugar form. It was higher when sugars were partly used in beverages. It was found in the studies conducted by Nguyen et al. [30] and Gao et al. [16] that excessive use of sugars derived from sweetened beverages is associated with elevated levels of plasma uric acid. Probably, the observed results were associated with a faster rate and other region of sugar absorption when the provided sugars were in fluid form.

The observed effect could also result from specific fructose metabolism. With excessive dietary intake of fructose, the use of adenosine triphosphate in phosphorylation of fructose increases. ATP breakdown results in elevated level of adenosine monophosphate which is the substrate for the uric acid synthesis, therefore its formation is enhanced.

In rats, uric acid is converted by urate oxidase to allantoin. In humans, uric acid is an end product of purine metabolism. Anthropoids and humans do not have urate oxidase activity, therefore purine metabolism ends with poorly soluble uric acid. Therefore, it may be assumed that elevated level of blood uric acid observed in the tested rats would be even higher in people.

\section{CONCLUSIONS}

The effect of HFCS-55 derived from diet on the parameters of carbohydrate and lipid metabolism was not equivalent of the effect of sucrose. Dietary use of HFCS-55 as a sweetener instead of sucrose causes adverse changes in blood parameters of carbohydrate and lipid metabolism, particularly when provided in beverages, as at comparable weight gains to that of sucrose.

Taking into account the value of HOMA-IR index value and atherogenic plasma indices, it was found that form of sugar intake is more important risk factor of insulin resistance and cardiovascular diseases than the sugar type. The HOMA-IR index value and atherogenic plasma indices were higher in animals provided with solid and fluid sugars, even with less sugar consumption, compared to those fed on solid sugars only.

Liquid form of sugar intake is more important insulin resistance and cardiovascular disease risk factor than the sugar type.

\section{Research funding}

This research received no specific grant from any funding agency in the public, commercial, or not-forprofit sectors. The research was supported by the West Pomeranian University of Technology in Szczecin.

\section{Conflict of interest}

The authors declare no potential conflicts of interest with respect to the research, authorship, and/or publication of this article.

\section{REFERENCES}

1. Akar F., Uludă̆ O., Aydın A., Aytekin Y.A., Elbeg S., Tuzcu M., Sahin K.: High-fructose corn syrup causes vascular dysfunction associated with metabolic disturbance in rats: protective effect of resveratrol. Food Chem Toxicol 2012;50:2135-2141. DOI: 10.1016/j. fct.2012.03.061

2. Akhavan T., Anderson G.H.: Effects of glucose-tofructose ratios in solutions on subjective satiety, food intake, and satiety hormones in young men. Am J Clin Nutr 2007;86:1354-1363. DOI: 10.1093/ajcn/86.5.1354

3. AOAC.: Association of Official Analytical and Chemists. Official Methods of Analysis. 20th Ed., Gaithersburg 2016.

4. Bhardwaj S., Bhattacharjee J., Bhatnagar M.K., Tyagi S.: Atherogenic Index of Plasma, Castelli Risk Index and Atherogenic Coefficient - new parameters in assessing cardiovascular risk. Int J Pharm Biol Sci 2013;3:359-364.

5. Bocarsly M.E., Powell E.S., Avena N.M., Hoebel B.G.: High-fructose corn syrup causes characteristics of obesity in rats: Increased body weight, body fat and triglyceride levels. Pharmacol Biochem Behav 2010;97:101106. DOI: 10.1016/j.pbb.2010.02.012

6. Bravo S., Lowndes J., Sinnett S., Yu Z., Rippe J.: Consumption of sucrose and high-fructose corn syrup does not increase liver fat or ectopic fat deposition in muscles. Appl Physiol Nutr Metab 2013;38:681-688. DOI: 10.1139/apnm-2012-0322 
7. Bruhns J.: The Reform of the EU Sugar Regime and its Effects on the Industry. Sugar J 2009;71:13-16.

8. Chen L., Appel L.J., Loria C., Lin P.H., Champagne C.M., Elmer P.J., Ard J.D., Mitchell D., Batch B.C., Svetkey L.P., Caballero B.: Reduction in consumption of sugar-sweetened beverages is associated with weight loss: the PREMIER trial. Am J Clin Nutr 2009;89:12991306. DOI: 10.3945/ajcn.2008.27240

9. David Wang D., Sievenpiper J., de Souza R.J., Cozma A.I., Chiavaroli L., Ha V., Mirrahimi A., Carleton A.J., Di Buono M., Jenkins A.L., Leiter L.A., Wolever T.M., Beyene J., Kendall C.W., Jenkins D.J.: Effect of fructose on postprandial triglycerides: A systematic review and meta-analysis of controlled feeding trials. Atherosclerosis 2014;232:125-133. DOI: 10.1016/j.atherosclerosis.2013.10.019

10. Dirlewanger M., Schneiter P., Jéquier E., Tappy L.: Effects of fructose on hepatic glucose metabolism in humans. Am J Physiol Endocrinol Metab 2000;279:E907E911. DOI: 10.1152/ajpendo.2000.279.4.E907

11. Elliott S.S., Keim N.L., Stern J.S., Teff K., Havel P.J.: Fructose, weight gain, and the insulin resistance syndrome. Am J Clin Nutr 2002;76:911-922. DOI: 10.1093/ ajcn/76.5.911

12. Ferder L., Ferder M.D., Inserra F.: The role of highfructose corn syrup in metabolic syndrome and hypertension. Curr Hypertens Rep 2010;12:105-112. DOI: 10.1007/s11906-010-0097-3

13. Figlewicz D.P., Ioannou G., Bennett Jay J., Kittleson S., Savard C., Roth C.L.: Effect of moderate intake of sweeteners on metabolic health in the rat. Physiol Behav 2009;98:618-624. DOI: 10.1016/j.physbeh.2009.09.016

14. Fowler S.P.G.: Low-calorie sweetener use and energy balance: Results from experimental studies in animals, and large-scale prospective studies in humans. Physiol Behav 2016;164(Pt B):517-523. DOI: 10.1016/j.physbeh.2016.04.047

15. Gadah N.S., Kyle L.E., Smith J.E., Brunstrom J.M., Rogers P.J.: No difference in compensation for sugar in a drink versus sugar in semi-solid and solid foods. Physiol Behav 2016;156:35-42. DOI: 10.1016/j.physbeh.2015.12.025

16. Gao X., Qi L., Qiao N., Choi H.K., Curhan G., Tucker K.L., Ascherio A.: Intake of added sugar and sugarsweetened drink and serum uric acid concentration in US men and women. Hypertension 2007;50:306-312. DOI: 10.1161/HYPERTENSIONAHA.107.091041

17. Goluch-Koniuszy Z., Sadowska J.: The effects of diet composition and vitamin B supplementation on the urine isoprostane concentration in rats. J Anim Feed Sci 2012;21:748-758.

18. Heden T.D., Liu Y., Kearney M.L., Kanaley J.A.: Weight classification does not influence the short-term endocrine or metabolic effects of high-fructose corn syrup-sweetened beverages. Appl Physiol Nutr Metab 2014;39:544-552. DOI: 10.1139/apnm-2013-0407

19. Hermans M.P., Sacks F.M., Ahn S.A., Rousseau M.F.: Non-HDL-cholesterol as valid surrogate to apolipoprotein B100 measurement in diabetes: Discriminant Ratio and unbiased equivalence. Cardiovasc Diabetol 2011;28:20. DOI: 10.1186/1475-2840-10-20
20. Kaufman M., Guglin M.: Uric acid in heart failure: a biomarker or therapeutic target? Heart Fail Rev 2013;18:177-186. DOI: 10.1007/s10741-012-9322-2

21. Kolderup A., Svihus B.: Fructose metabolism and relation to atherosclerosis, type 2 diabetes, and obesity. J Nutr Metab 2015;823081. DOI: 10.1155/2015/823081

22. Le M.T., Frye R.F., Rivard C.J., Cheng J., McFann K.K., Segal M.S., Johnson R.J., Johnson J.A.: Effects of high-fructose corn syrup and sucrose on the pharmacokinetics of fructose and acute metabolic and hemodynamic responses in healthy subjects. Metabolism 2012;61:641-651. DOI: 10.1016/j.metabol.2011.09.013

23. Light H.R., Tanzi E., Gigliotti J., Morgan K., Tou J.C.: The type of caloric sweetener added to water influences weight gain, fat mass, and reproduction in growing Sprague-Dawley female rats. Exp Biol Med (Maywood) 2009;234:651-661.

24. Lowndes J., Sinnett S., Pardo S., Nguyen V.T., Melanson K.J., Yu Z., Lowther B.E., Rippe J.M.: The effect of normally consumed amounts of sucrose or high fructose corn syrup on lipid profiles, body composition and related parameters in overweight/obese subjects. Nutrients 2014;6:1128-1144. DOI: 10.3390/nu6031128

25. Lustig R.H., Schmidt L.A., Brindis C.D.: Public health: The toxic truth about sugar. Nature 2012;482:27-29. DOI: $10.1038 / 482027 \mathrm{a}$

26. Ma J., Jacques P.F., Meigs J.B., Fox C.S., Rogers G.T., Smith C.E., Hruby A., Saltzman E., McKeown N.M.: Sugar-Sweetened beverage but not diet soda consumption is positively associated with progression of insulin resistance and prediabetes. J Nutr 2016;146:2544-2550. DOI: $10.3945 /$ jn.116.234047

27. Melanson K.J., Zukley L., Lowndes J., Nguyen V., Angelopoulos T.J., Rippe J.M.: Effects of high-fructose corn syrup and sucrose consumption on circulating glucose, insulin, leptin, and ghrelin and on appetite in normal-weight women. Nutrition 2007;23:103-112. DOI: 10.1016/j.nut.2006.11.001

28. Monsivais P., Perrigue M.M., Drewnowski A.: Sugars and satiety: does the type of sweetener make a difference? Am J Clin Nutr 2007;86:116-123.

29. Nair D., Carrigan T.P., Curtin R.J., Popovic Z.B., Kuzmiak S., Schoenhagen P., Flamm S.D., Desai M.Y.: Association of total cholesterol/high-density lipoprotein cholesterol ratio with proximal coronary atherosclerosis detected by multislice computed tomography. Prev Cardiol 2009;12:19-26. DOI: 10.1111/j.17517141.2008.00011.x

30. Nguyen S., Choi H.K., Lustig R.H., Hsu C.Y.: Sugarsweetened beverages, serum uric acid, and blood pressure in adolescents. J Pediatr 2009;154:807-813. DOI: 10.1016/j.jpeds.2009.01.015

31. O'Connor T.M., Yang S.J., Nicklas T.A.: Beverage intake among preschool children and its effect on weight status. Pediatrics 2006;118:e1010-e1018. DOI: 10.1542/peds.2005-2348

32. Pan A., Hu F.B.: Effects of carbohydrates on satiety: differences between liquid and solid food. Curr Opin Clin Nutr Metab Care 2011;14:385-390. DOI: 10.1097/ MCO.0b013e328346df36 
33. Roy H.J., Keenan M.J., Zablah-Pimentel E., Hegsted M., Bulot L., O’Neil C.E., Bunting L.D., Fernandez J.M.: Adult female rats defend "appropriate" energy intake after adaptation to dietary energy. Obes Res 2003;11:1214-1222. DOI: 10.1038/oby.2003.167

34. Sadowska J., Bruszkowska M.: Comparing the effects of sucrose and high-fructose corn syrup on lipid metabolism and the risk of cardiovascular disease in male rats. Acta Sci Pol Technol Aliment 2017;16:231-240. DOI: $10.17306 /$ J.AFS.0482

35. Saito H., Kato M., Yoshida A., Naito M.: The ingestion of a fructose-containing beverage combined with fat cream exacerbates postprandial lipidemia in young healthy women. J Atheroscler Thromb 2015;22:85-94. DOI: $10.5551 /$ jat.22681

36. Samuel V.T., Shulman G.I.: Mechanisms for Insulin Resistance: Common Threads and Missing Links. Cell 2012;148:852-871. DOI: 10.1016/j.cell.2012.02.017

37. Soenen S., Westerterp-Plantenga M.S.: No differences in satiety or energy intake after high-fructose corn syrup, sucrose, or milk preloads. Am J Clin Nutr 2007;86:1586-1594. DOI: 10.1093/ajcn/86.5.1586

38. Tappy L., Lê K.A.: Metabolic effects of fructose and the worldwide increase in obesity. Physiol Rev 2010;90:2346. DOI: 10.1152/physrev.00019.2009

39. Taylan E., Tuncel E.P.: Distribution of LDL subgroups in patients with hyperlipidemia. Turk J Med Sci 2016;46:374-380. DOI: doi:10.3906/sag-1410-40
40. Tsanzi E., Light H.R., Tou J.C.: The effect of feeding different sugar-sweetened beverages to growing female Sprague-Dawley rats on bone mass and strength. Bone 2008;42:960-968. DOI: 10.1016/j.bone.2008.01.020

41. Yang Q., Zhang Z., Gregg E.W., Flanders W.D., Merritt R., Hu F.B.: Added sugar intake and cardiovascular diseases mortality among US adults. JAMA Intern Med 2014;174:516-524. DOI: 10.1001/jamainternmed.2013.13563

42. Yu Z., Lowndes J., Rippe J.: High-fructose corn syrup and sucrose have equivalent effects on energy-regulating hormones at normal human consumption levels. Nutr Res 2013;3:1043-1052. DOI: 10.1016/j.nutres.2013.07.020

43. Zhi L., Yuzhang Z., Tianliang H., Hisatome I., Yamamoto T., Jidong1 C.: High uric acid induces insulin resistance in cardiomyocytes in vitro and in vivo. PLOS One, 2016;11:e0147737. DOI: 10.1371/journal. pone. 0147737

44. Zupanič N., Miklavec K., Kušar A., Žmitek K., Fidler Mis N., Pravst I.: Total and Free Sugar Content of Pre-Packaged Foods and Non-Alcoholic Beverages in Slovenia. Nutrients, 2018;10:151. DOI: 10.3390/ nu10020151

Received: 29.10.2018

Accepted: 19.02.2019

This article is available in Open Access model and licensed under a Creative Commons Attribution-Non Commercial 3.0.Poland License (CC-BY-NC) available at: http://creativecommons.org/licenses/by-nc/3.0/pl/deed.en 